\title{
THE PREFERENCES OF THE EUROPEAN BEAVER CASTOR FIBER FOR TREES AND SHRUBS IN RIPARIAN ZONES
}

\author{
JANISZEWSKI, P. $.^{*}-$ KOLASA, SZ. ${ }^{2}-$ STRYCHALSKI , J. ${ }^{1}$ \\ ${ }^{1}$ University of Warmia and Mazury, Faculty of Animal Bioengineering, Department of Fur- \\ Bearing Animal Breeding and Game Management, Oczapowskiego 5, 10-719 Olsztyn, Poland \\ ${ }^{2}$ Polesie National Park, Poland \\ e-mail: szymon.kolasa@poleskipn.pl \\ *Corresponding author \\ e-mail: janisz@uwm.edu.pl \\ (Received $12^{\text {th }}$ Apr 2017; accepted $8^{\text {th }}$ Jun 2017)
}

\begin{abstract}
The aim of this study was to identify selected factors that influence the preferences of European beavers Castor fiber for various tree species in three different riparian zones. The study was realized during the November and December of 2015, in 8 research sites located in the immediate vicinity of watercourses. To determine the foraging preferences of beavers, there were analyzed the species and diameter of trees in each riparian zone. Beavers cut down $33.44 \%$ trees and partly cut $5.2 \%$ trees from 2500 total identified. The results of this study indicate that willows, aspens and alders are most commonly cut by beavers in the fall and winter. In addition to tree species and diameter, beaver foraging preferences are also affected by the distance from the shoreline of a river, watercourse or a water body.
\end{abstract}

Keywords: Castor fiber, food, cutting tree

\section{Introduction}

The European beaver Castor fiber is a herbivore whose digestive system has adapted to plant foods. The beaver has a relatively long small intestine which is equal to around six-times its body length. The large intestine is also relatively large, and its capacity corresponds to twice the volume of the beaver stomach (Vecherskii et al., 2006). According to Dezhkin et al. (1986), stomach capacity in adult beavers is $350-1400 \mathrm{~cm}^{3}$, and the digestion process lasts 30-48 hours. In a study conducted in the Voronezh Nature Reserve in Russia, Dezhkin et al. (1986) demonstrated that the daily energy demand of one-year-old beavers reached 1400 calories, whereas two-year-old and older beavers required 1700 calories per day. The daily energy intake of young animals up to one year of age was estimated at 900 calories.

The annual food intake of an adult European beaver can be as high as $241 \mathrm{~kg}$. In Ural, adult individuals consumed around $111.8 \mathrm{~kg}$ of food annually in areas overgrown mainly with birches and alders, and $159.8 \mathrm{~kg}$ in sites with a predominance of aspens (Janiszewski and Misiukiewicz, 2012). According to Starinovic (1998), beavers consume around $100 \mathrm{~kg}$ of aspens and $230 \mathrm{~kg}$ of grass per year. Wood cutting is an important element of beaver behavior (Danilov and Fyodorov, 2015), and it plays a vital role in plant succession and biotope transformations in beaver habitats (Janiszewski et al., 2014, Logofet et al., 2016). Information about beaver foraging preferences can be used to model the utilization of plant foods by beaver families (Nummi, 1989) and to describe environmental changes in riparian zones inhabited by beavers (Rosell et al., 2005). Therefore, the aim of this study was to identify selected factors that influence the preferences of European beavers for various tree species in riparian zones. 


\section{Materials and Methods}

We conducted the study in the Polesie National Park in eastern Poland $\left(51^{\circ} 27^{\prime} 19^{\prime \prime} \mathrm{N} ; 23^{\circ} 10^{\prime} 24^{\prime \prime} \mathrm{E}\right)$ (Figure 1). The Park occupies a total area of 9764 ha, of which 1211 ha is privately owned.



Figure 1. Localization of Polesie National Park in Poland

The Polesie National Park covers wetlands and peat bogs which create an ideal habitat for beavers. The park features lakes (Łukie, Długie, Moszne and Karaśne) which are characterized by varied trophic levels, small area and relatively small depth. The watercourse network in the Polesie National Park is composed of small and highly anthropogenic rivers (Mietiułka, Piwonia and Włodawa). Numerous ditches, channels and canals, which are permanently or seasonally filled with water, constitute an ideal habitat for beavers. Small water bodies, such as former peat pits, marshes and astatic reservoirs, also play an important role in the ecosystem. Around 5\% of the park's area is covered with water. The Scots pine Pinus sylvestris is the predominant tree species in the Polesie National Park (36.7\% of woodland area). Other dominant species that form tree stands are the downy birch Betula pubescens (31.9\%) and the black alder Alnus glutinosa (20.8\%) (Radwan, 2002).

We conducted the study in November and December of 2015, in 8 research sites located in the immediate vicinity of watercourses. For the needs of the study, we labeled the research sites with numbers 1 to 8 . Every study area was composed of a riparian zone with a length of $200 \mathrm{~m}$ and a width of $15 \mathrm{~m}$. We permanently marked the limits of every research site during the study. We found lodges, burrows and dams in all study areas or in their immediate vicinity, which indicated the presence of active beaver families that had been previously monitored by the Park's employees.

The study areas covered various plant formations. Four sites occupied woodlands (sites 1, 2, 3 and 4), two study areas were composed of meadows (sites 5 and 6), and two study areas occupied non-forest tree and shrub communities (sites 7 and 8). We searched for and identified the species of trees and shrubs in the examined study areas (Table 1). 
Table 1. The number (No.) and percentage (\%) of tree species in the analyzed study areas

\begin{tabular}{|c|c|c|c|c|c|c|c|c|c|c|}
\hline \multirow{2}{*}{\multicolumn{2}{|c|}{ Species }} & \multicolumn{8}{|c|}{ Study area } & \multirow{3}{*}{$\begin{array}{r}\text { Tota } \\
724 \\
\end{array}$} \\
\hline & & \multirow{2}{*}{\begin{tabular}{|c|}
1 \\
238
\end{tabular}} & \multirow{2}{*}{$\begin{array}{c}2 \\
11 \\
\end{array}$} & \multirow{2}{*}{\begin{tabular}{|c|}
3 \\
55
\end{tabular}} & \multirow{2}{*}{\begin{tabular}{|c|}
4 \\
98
\end{tabular}} & \multirow{2}{*}{$\begin{array}{c}5 \\
63\end{array}$} & \multirow{2}{*}{$\begin{array}{c}6 \\
165\end{array}$} & \multirow{2}{*}{\begin{tabular}{|c|}
7 \\
94 \\
\end{tabular}} & \multirow{2}{*}{$\begin{array}{l}8 \\
0\end{array}$} & \\
\hline Downy birch & No. & & & & & & & & & \\
\hline Betula pubescens & $\%$ & 32.9 & 1.6 & 7.8 & 13.6 & 8.2 & 22.9 & 13.0 & 0 & 100 \\
\hline \multirow{2}{*}{$\begin{array}{c}\text { Black alder } \\
\text { Alnus glutinosa }\end{array}$} & No. & 7 & 359 & 0 & 13 & 60 & 138 & 10 & 132 & 719 \\
\hline & $\%$ & 1.0 & 49.9 & 0 & 1.8 & 8.3 & 19.2 & 1.4 & 18.4 & 100 \\
\hline \multirow{2}{*}{$\begin{array}{l}\text { Common aspen } \\
\text { Populus tremula }\end{array}$} & No. & 63 & 0 & 5 & 2 & 42 & 20 & 119 & 6 & 257 \\
\hline & $\%$ & 24.5 & 0 & 1.9 & 0.8 & 16.4 & 7.8 & 46.3 & 2.3 & 100 \\
\hline \multirow{2}{*}{$\begin{array}{l}\text { Gray willow } \\
\text { Salix cinerea }\end{array}$} & No. & 41 & 0 & 4 & 5 & 36 & 129 & 0 & 0 & 215 \\
\hline & $\%$ & 19.1 & 0 & 1.9 & 2.3 & 16.7 & 60 & 0 & 0 & 100 \\
\hline \multirow{2}{*}{$\begin{array}{l}\text { White willow } \\
\text { Salix alba }\end{array}$} & No. & 0 & 35 & 0 & 0 & 0 & 0 & 0 & 107 & 142 \\
\hline & $\%$ & 0 & 24.6 & 0 & 0 & 0 & 0 & 0 & 75.4 & 100 \\
\hline \multirow{2}{*}{$\begin{array}{l}\text { Small-leaved lime } \\
\text { Tilia cordata }\end{array}$} & No. & 0 & 0 & 5 & 16 & 60 & 36 & 0 & 0 & 117 \\
\hline & $\%$ & 0 & 0 & 4.2 & 13.7 & 51.3 & 30.8 & 0 & 0 & 100 \\
\hline \multirow{2}{*}{$\begin{array}{c}\text { Pedunculate oak } \\
\text { Quercus robur }\end{array}$} & No. & 7 & 5 & 0 & 0 & 2 & 0 & 40 & 38 & 92 \\
\hline & $\%$ & 7.6 & 5.4 & 0 & 0 & 2.2 & 0 & 43.5 & 41.3 & 100 \\
\hline \multirow{2}{*}{$\begin{array}{l}\text { Alder buckthorn } \\
\text { Frangula alnus }\end{array}$} & No. & 10 & 28 & 0 & 0 & 15 & 3 & 12 & 0 & 68 \\
\hline & $\%$ & 14.7 & 41.2 & 0 & 0 & 22.1 & 4.4 & 17.6 & 0 & 100 \\
\hline \multirow{2}{*}{$\begin{array}{c}\text { Scots pine } \\
\text { Pinus sylvestris }\end{array}$} & No. & 11 & 8 & 0 & 4 & 0 & 0 & 24 & 5 & 52 \\
\hline & $\%$ & 21.2 & 15.3 & 0 & 7.7 & 0 & 0 & 46.2 & 9.6 & 100 \\
\hline \multirow{2}{*}{$\begin{array}{c}\text { Norway maple } \\
\text { Acer platanoides }\end{array}$} & No. & 0 & 1 & 0 & 0 & 3 & 0 & 0 & 30 & 34 \\
\hline & $\%$ & 0 & 3.0 & 0 & 0 & 8.8 & 0 & 0 & 88.2 & 100 \\
\hline \multirow{2}{*}{$\begin{array}{l}\text { Norway spruce } \\
\text { Picea abies }\end{array}$} & No. & 21 & 4 & 0 & 0 & 0 & 0 & 0 & 0 & 25 \\
\hline & $\%$ & 84.0 & 26.0 & 0 & 0 & 0 & 0 & 0 & 0 & 100 \\
\hline \multirow{2}{*}{$\begin{array}{c}\text { Common ash } \\
\text { Fraxinus excelsior }\end{array}$} & No. & 0 & 0 & 0 & 23 & 0 & 0 & 0 & 0 & 23 \\
\hline & $\%$ & 0 & 0 & 0 & 100 & 0 & 0 & 0 & 0 & 100 \\
\hline \multirow{2}{*}{$\begin{array}{l}\text { Common hawthorn } \\
\text { Crataegus mon. }\end{array}$} & No. & 0 & 0 & 0 & 0 & 0 & 4 & 0 & 8 & 12 \\
\hline & $\%$ & 0 & 0 & 0 & 0 & 0 & 33.3 & 0 & 66.7 & 100 \\
\hline \multirow{2}{*}{$\begin{array}{c}\text { European pear } \\
\text { Pyrus communis }\end{array}$} & No. & 0 & 0 & 0 & 0 & 0 & 0 & 0 & 10 & 10 \\
\hline & $\%$ & 0 & 0 & 0 & 0 & 0 & 0 & 0 & 100 & 100 \\
\hline \multirow{2}{*}{$\begin{array}{l}\text { Field elm } \\
\text { Ulmus minor }\end{array}$} & No. & 0 & 4 & 0 & 0 & 0 & 0 & 0 & 0 & 4 \\
\hline & $\%$ & 0 & 100 & 0 & 0 & 0 & 0 & 0 & 0 & 100 \\
\hline Common hornbeam & No. & 1 & 1 & 0 & 0 & 0 & 0 & 0 & 1 & 3 \\
\hline Carpinus betulus & $\%$ & 33.3 & 33.3 & 0 & 0 & 0 & 0 & 0 & 33.3 & 100 \\
\hline Rowan & No. & 0 & 0 & 0 & 0 & 0 & 0 & 3 & 0 & 3 \\
\hline Sorbus aucupar. & $\%$ & 0 & 0 & 0 & 0 & 0 & 0 & 100 & 0 & 100 \\
\hline Total & No. & 399 & 456 & 69 & 161 & 281 & 495 & 302 & 337 & 2500 \\
\hline
\end{tabular}

We determined the number and percentage of each tree species in every study area. We measured the diameter of all tree trunks $20 \mathrm{~cm}$ above ground, to the nearest $1 \mathrm{~cm}$, with the use of a caliper. We divided the trees growing in the study areas into three classes based on the degree of damage caused by beavers:

- I - trees cut down by beavers,

- II - partly cut trees,

- 0 - undamaged trees.

We divided every study area into the following zones (belts):

- $5 \mathrm{~m}$ from the shoreline (riparian zone A),

- $5 \mathrm{~m}$ to $10 \mathrm{~m}$ from the shoreline (riparian zone B),

- $10 \mathrm{~m}$ to $15 \mathrm{~m}$ from the shoreline (riparian zone $\mathrm{C}$ ). 
To determine the foraging preferences of beavers, we analyzed the species and diameter of trees in each riparian zone. We also described the influence of environmental factors on beaver preferences for the analyzed tree species.

Statistical analyses were processed by on way ANOVA in non-orthogonal design using Tukey HSD test and with Fisher's exact test.

\section{Results}

We found a total of 17 tree species in the examined study areas (Table 1). The study areas were occupied by a total of 2500 trees. The predominant species were the downy birch (724 trees), black alder (719 trees) and aspen (257 trees).

Beavers cut down 836 trees $(33.44 \%)$ and partly cut 130 trees $(5.2 \%)$. We found the highest number of trees (495) in study area No. 8, which accounted for $19.8 \%$ of trees in all research sites. We also observed the highest number of cut trees (264) in study area No. 8, which accounted for $31.58 \%$ of trees cut in all research sites (Table 2).

Table 2. Percentage (\%) of trees representing different damage classes in the particularly study areas

\begin{tabular}{|c|c|c|c|c|c|c|c|c|c|}
\hline \multirow{2}{*}{ Species } & \multirow{2}{*}{ Class } & \multicolumn{8}{|c|}{ Study area } \\
\hline & & 1 & 2 & 3 & 4 & 5 & 6 & 7 & 8 \\
\hline \multirow{4}{*}{ Betula pubescens } & I & 31.3 & 0 & 0 & 0 & 12.0 & 18.4 & 7.37 & 30.9 \\
\hline & II & 0 & 0 & 0 & 0 & 0 & 0 & 42.9 & 57.1 \\
\hline & 0 & 34.0 & 18.8 & 2.2 & 0 & 14.4 & 3.0 & 8.8 & 18.8 \\
\hline & Total & 32.9 & 13.0 & 1.5 & 0 & 13.5 & 7.6 & 8.7 & 22.8 \\
\hline \multirow{4}{*}{ Alnus glutinosa } & $\mathrm{I}$ & 0 & 0 & 33.3 & 14.3 & 0 & 0 & 9.5 & 42.9 \\
\hline & II & 0 & 0 & 71.2 & 16.7 & 3.03 & 0 & 6.1 & 3.0 \\
\hline & 0 & 1.2 & 1.7 & 49.3 & 19.0 & 1.9 & 0 & 8.5 & 18.5 \\
\hline & Total & 1.0 & 1.4 & 49.9 & 18.4 & 1.8 & 0 & 8.3 & 19.2 \\
\hline \multirow{4}{*}{ Populus tremula } & I & 36.8 & 15.4 & 0 & 4.3 & 0 & 3.4 & 27.3 & 12.8 \\
\hline & II & 20.0 & 50.0 & 0 & 3.3 & 3.3 & 3.3 & 13.3 & 6.7 \\
\hline & 0 & 12.7 & 78.2 & 0 & 0 & 0.9 & 0 & 5.5 & 2.7 \\
\hline & Total & 24.5 & 46.3 & 0 & 2.3 & 0.8 & 1.9 & 16.3 & 7.8 \\
\hline \multirow{4}{*}{ Salix cinerea } & $\mathrm{I}$ & 19.3 & 0 & 0 & 0 & 2.4 & 0.9 & 17.0 & 60.4 \\
\hline & II & 0 & 0 & 0 & 0 & 0 & 0 & 0 & 0 \\
\hline & 0 & 0 & 0 & 0 & 0 & 0 & 6.7 & 0 & 33.3 \\
\hline & Total & 19.1 & 0 & 0 & 0 & 2.3 & 1.9 & 16.7 & 60 \\
\hline \multirow{4}{*}{ Salix alba } & $\mathrm{I}$ & 0 & 0 & 15.24 & 84.76 & 0 & 0 & 0 & 0 \\
\hline & II & 0 & 0 & 0 & 100.0 & 0 & 0 & 0 & 0 \\
\hline & 0 & 0 & 0 & 54.3 & 45.7 & 0 & 0 & 0 & 0 \\
\hline & Total & 0 & 0 & 24.7 & 75.3 & 0 & 0 & 0 & 0 \\
\hline \multirow{4}{*}{ Tilia cordata } & $\mathrm{I}$ & 0 & 0 & 0 & 0 & 4.6 & 4.6 & 50.8 & 40.0 \\
\hline & II & 0 & 0 & 0 & 0 & 16.7 & 0 & 83.3 & 0 \\
\hline & 0 & 0 & 0 & 0 & 0 & 26.1 & 4.3 & 47.8 & 21.7 \\
\hline & Total & 0 & 0 & 0 & 0 & 13.7 & 4.3 & 51.3 & 30.7 \\
\hline \multirow{4}{*}{ Quercus robur } & $\mathrm{I}$ & 17.6 & 17.5 & 29.4 & 29.4 & 0 & 0 & 5.9 & 0 \\
\hline & II & 0 & 0 & 0 & 100 & 0 & 0 & 0 & 0 \\
\hline & 0 & 5.7 & 52.9 & 0 & 40 & 0 & 0 & 1.4 & 0 \\
\hline & Total & 7.6 & 43.5 & 5.4 & 41.3 & 0 & 0 & 2.2 & 0 \\
\hline \multirow{4}{*}{ Frangula alnus } & $\mathrm{I}$ & 41.2 & & 11.8 & 0 & 0 & 0 & 47.0 & 0 \\
\hline & II & 0 & 12.5 & 75.0 & 0 & 0 & 0 & 12.5 & 0 \\
\hline & 0 & 7.0 & 25.6 & 46.5 & 0 & 0 & 0 & 14.0 & 7.0 \\
\hline & Total & 14.7 & 17.6 & 41.2 & 0 & 0 & 0 & 22.1 & 4.4 \\
\hline
\end{tabular}




\begin{tabular}{|c|c|c|c|c|c|c|c|c|c|}
\hline \multirow{4}{*}{ Pinus sylvestris } & $\mathrm{I}$ & 0 & 0 & 0 & 0 & 0 & 0 & 0 & 0 \\
\hline & II & 0 & 100.0 & 0 & 0 & 0 & 0 & 0 & 0 \\
\hline & 0 & 21.6 & 45.1 & 15.7 & 9.8 & 7.84 & 0 & 0 & 0 \\
\hline & Total & 21.2 & 46.2 & 15.4 & 9.6 & 7.7 & 0 & 0 & 0 \\
\hline \multirow{4}{*}{ Acer platanoides } & $\mathrm{I}$ & 0 & 0 & 0 & 100.0 & 0 & 0 & 0 & 0 \\
\hline & II & 0 & 0 & 0 & 100.0 & 0 & 0 & 0 & 0 \\
\hline & 0 & 0 & 0 & 3.2 & 87.1 & 0 & 0 & 9.7 & 0 \\
\hline & Total & 0 & 0 & 2.9 & 88.2 & 0 & 0 & 8.8 & 0 \\
\hline \multirow{4}{*}{ Picea abies } & $\mathrm{I}$ & 0 & 0 & 0 & 0 & 0 & 0 & 0 & 0 \\
\hline & II & 0 & 0 & 0 & 0 & 0 & 0 & 0 & 0 \\
\hline & 0 & 84.0 & 0 & 16.0 & 0 & 0 & 0 & 0 & 0 \\
\hline & Total & 84.0 & 0 & 16.0 & 0 & 0 & 0 & 0 & 0 \\
\hline \multirow{4}{*}{ Fraxinus excelsior } & $\mathrm{I}$ & 0 & 0 & 0 & 0 & 100 & 0 & 0 & 0 \\
\hline & II & 0 & 0 & 0 & 0 & 0 & 0 & 0 & 0 \\
\hline & 0 & 0 & 0 & 0 & 0 & 100 & 0 & 0 & 0 \\
\hline & Total & 0 & 0 & 0 & 0 & 100 & 0 & 0 & 0 \\
\hline \multirow{4}{*}{ Crataegus mon. } & $\mathrm{I}$ & 0 & 0 & 0 & 83.3 & 0 & 0 & 0 & 16.7 \\
\hline & II & 0 & 0 & 0 & 100.0 & 0 & 0 & 0 & 0 \\
\hline & 0 & 0 & 0 & 0 & 40.0 & 0 & 0 & 0 & 60.0 \\
\hline & Total & 0 & 0 & 0 & 66.7 & 0 & 0 & 0 & 33.3 \\
\hline \multirow{4}{*}{ Pyrus communis } & $\mathrm{I}$ & 0 & 0 & 0 & 100.0 & 0 & 0 & 0 & 0 \\
\hline & II & 0 & 0 & 0 & 100.0 & 0 & 0 & 0 & 0 \\
\hline & 0 & 0 & 0 & 0 & 100.0 & 0 & 0 & 0 & 0 \\
\hline & Total & 0 & 0 & 0 & 100.0 & 0 & 0 & 0 & 0 \\
\hline \multirow{4}{*}{ Ulmus minor } & $\mathrm{I}$ & 0 & 0 & 0 & 0 & 0 & 0 & 0 & 0 \\
\hline & II & 0 & 0 & 0 & 0 & 0 & 0 & 0 & 0 \\
\hline & 0 & 0 & 0 & 100.0 & 0 & 0 & 0 & 0 & 0 \\
\hline & Total & 0 & 0 & 100.0 & 0 & 0 & 0 & 0 & 0 \\
\hline \multirow{4}{*}{ Carpinus betulus } & $\mathrm{I}$ & 50.0 & 0 & 50.0 & 0 & 0 & 0 & 0 & 0 \\
\hline & II & 0 & 0 & 0 & 0 & 0 & 0 & 0 & 0 \\
\hline & 0 & 0 & 0 & 0 & 100.0 & 0 & 0 & 0 & 0 \\
\hline & Total & 33.3 & 0 & 33.3 & 33.3 & 0 & 0 & 0 & 0 \\
\hline \multirow{4}{*}{ Sorbus aucuparia } & I & 0 & 0 & 0 & 0 & 0 & 0 & 0 & 0 \\
\hline & II & 0 & 0 & 0 & 0 & 0 & 0 & 0 & 0 \\
\hline & 0 & 0 & 100 & 0 & 0 & 0 & 0 & 0 & 0 \\
\hline & Total & 0 & 100 & 0 & 0 & 0 & 0 & 0 & 0 \\
\hline
\end{tabular}

In the group of identified tree species (Table 1), the only species that were not damaged by beavers were Scots pines, common spruces, rowans and field elms (Table 2).

Downy birch (Betula pubescens) was the predominant tree species in all the study areas, and of the 724 identified trees, 217 trees (29.9\%) were cut by beavers (Table 2). We found the highest number of birches (238) in study area No. 1, which accounted for $32.87 \%$ of birches in all research sites (Table 2). We also identified the highest number of cut birches (68) in research site No. 1 which occupied a wooded area. In site No. 1, cut birches accounted for $31.34 \%$ of all birches cut by beavers.

Downy birch was most prevalent in riparian zone A where we identified 329 trees (45.4\%). We found 185 birches $(25.6 \%)$ in riparian zone B, and 210 birches (29\%) in riparian zone $\mathrm{C}$. The highest number of birches was cut in zone A (151 trees, 45.9\%), followed by zone B (38 trees, 20.54\%) and zone C (28 trees, 13.33\%) (Tables 5, 6, 7).

The diameter of birches in the study areas ranged from 3 to $46 \mathrm{~cm}$. The mean diameter of all analyzed birches was $11 \mathrm{~cm}$. The mean diameter of birches was $10.8 \mathrm{~cm}$ 
in zone $\mathrm{A}, 12.5 \mathrm{~cm}$ in zone $\mathrm{B}$, and $9.9 \mathrm{~cm}$ in zone $\mathrm{C}$. The mean diameter of birches cut by beavers was $6.7 \mathrm{~cm}$.

Table 3. Percentage (\%) of trees representing different damage classes in particularly riparian zones (mean value of 1-8 study areas)

\begin{tabular}{|c|c|c|c|c|c|c|c|}
\hline \multirow{3}{*}{ Species } & \multirow{3}{*}{ Class } & \multicolumn{6}{|c|}{ Riparian zone } \\
\hline & & \multicolumn{2}{|c|}{$\mathbf{A}$} & \multicolumn{2}{|c|}{ B } & \multicolumn{2}{|c|}{$\mathbf{C}$} \\
\hline & & mean & SD & mean & SD & mean & SD \\
\hline \multirow{3}{*}{ Betula pubescens } & $\mathrm{I}$ & $6,8^{\mathrm{a}}$ & 0,99 & $7,2^{\mathbf{A}}$ & 0,62 & $5,4^{\mathrm{Aa}}$ & 0,48 \\
\hline & II & 13,8 & 1,48 & 16 & - & - & - \\
\hline & 0 & $14,3^{\mathbf{A}}$ & 0,92 & $13,9^{\mathbf{A B}}$ & 1,17 & $10,5^{\mathbf{A B}}$ & 0,66 \\
\hline \multirow{3}{*}{ Alnus glutinosa } & I & $11,0^{\mathbf{a}}$ & 1,18 & $7,5 \mathrm{a}$ & 0,77 & 10 & 3,82 \\
\hline & II & 11,2 & 1,19 & - & - & - & - \\
\hline & 0 & $11,5^{\mathrm{Aa}}$ & 0,98 & $15,2^{\mathrm{a}}$ & 1,21 & $19,5^{\mathbf{A}}$ & 1,20 \\
\hline \multirow{3}{*}{ Populus tremula } & I & $15,5^{\mathbf{b}}$ & 0,86 & $19,6^{\text {ab }}$ & 1,04 & $12,9^{\mathrm{a}}$ & 1,00 \\
\hline & II & $20,2^{\text {ab }}$ & 0,69 & $25,1^{a}$ & 1,19 & $29,4^{\mathrm{b}}$ & 3,82 \\
\hline & 0 & 16,5 & 0,76 & 16,4 & 0,62 & 16,5 & 1,24 \\
\hline \multirow{3}{*}{ Salix cinerea } & $\mathrm{I}$ & 3,0 & 0.34 & 2,4 & 0,32 & 2,6 & 0,18 \\
\hline & II & 0 & - & - & - & - & - \\
\hline & 0 & 8,0 & 2,65 & - & - & - & - \\
\hline \multirow{3}{*}{ Salix alba } & I & 8 & 0,62 & 8 & 0,65 & 25,5 & 2,69 \\
\hline & II & 7 & 1,70 & - & - & - & - \\
\hline & 0 & 10 & 0,86 & - & - & 28 & 4,27 \\
\hline \multirow{3}{*}{ Tilia cordata } & I & $4,5^{\mathrm{a}}$ & 0,62 & $4,2^{\mathrm{a}}$ & 0,58 & 4,8 & 0,93 \\
\hline & II & 10,3 & 3,69 & 6,5 & 1,63 & 6 & \\
\hline & 0 & 6,9 & 0,71 & $7,5^{\mathrm{a}}$ & 0,74 & $6,05^{\mathrm{a}}$ & 0,52 \\
\hline \multirow{3}{*}{ Quercus robur } & I & 5,3 & 2,05 & 8,5 & 1,21 & 16 & 1,48 \\
\hline & II & - & & - & & 18,4 & 1,99 \\
\hline & 0 & $8,2^{\mathrm{A}}$ & 0,74 & $7^{\mathrm{a}}$ & 0,73 & $16,9^{\mathrm{Aa}}$ & 0,94 \\
\hline \multirow{3}{*}{ Frangula alnus } & I & 4,7 & 0,53 & - & & 3,8 & 0,33 \\
\hline & II & 8,1 & 0,78 & 6 & - & - & \\
\hline & 0 & $4,1^{\mathrm{a}}$ & 0,25 & 4 & - & $5,9^{\mathrm{a}}$ & 0,64 \\
\hline \multirow{3}{*}{ Pinus sylvestris } & $\mathrm{I}$ & - & & - & & - & \\
\hline & II & 4 & - & - & & - & \\
\hline & 0 & 19,5 & 2,63 & $19^{\mathbf{A}}$ & 1,82 & $23,9^{\mathbf{A}}$ & 1,84 \\
\hline
\end{tabular}

A, B $-\mathrm{p} \leq 0,01$

$\mathrm{a}, \mathrm{b}-\mathrm{p} \leq 0,05$

Table 4. The number and percentage of trees with different diameters cut in the analyzed riparian zones

\begin{tabular}{|c|c|c|c|c|c|c|c|c|}
\hline \multirow{2}{*}{ Diameter } & \multicolumn{9}{|c|}{ Riparian zone } \\
\cline { 2 - 9 } & \multicolumn{2}{|c|}{$\mathrm{A}$} & \multicolumn{2}{|c|}{ B } & \multicolumn{2}{|c|}{ C } & \multicolumn{2}{c|}{ Total } \\
\cline { 2 - 9 } & $\mathrm{N}$ & $\%$ & $\mathrm{n}$ & $\%$ & $\mathrm{n}$ & $\%$ & $\mathrm{n}$ & $\%$ \\
\hline up to $15 \mathrm{~cm}$ & 501 & 90.9 & 120 & 79.0 & 114 & 85.72 & 735 & 87.9 \\
\hline above $15 \mathrm{~cm}$ & 50 & 9.1 & 32 & 21.0 & 19 & 14.28 & 101 & 12.1 \\
\hline Total & 551 & 65.91 & 152 & 18.18 & 133 & 15.91 & 836 & 100 \\
\hline
\end{tabular}

Black alder (Alnus glutinosa) was represented by 719 trees, of which 63 (8.76\%) were cut by beavers. The species was most prevalent (359 trees) in study area No. 3, where it accounted for $49.93 \%$ of all black alder trees (Table 1). We observed the 
highest number of cut black alders (27) in study area No. 8 which was occupied by nonforest tree and shrub communities. In site No. 8, cut black alders represented $42.86 \%$ of all black alders cut by beavers.

Black alder was most prevalent in zone A (587 trees, $81.6 \%$ ). Zone B was occupied by 81 black alders $(11.3 \%)$, and zone $\mathrm{C}-$ by $51(7.1 \%)$. We found the highest number of cut black alders in zone A (52 trees, 8.9\%). Beavers cut 8 black alders in zone B (9.9\%) and only 3 trees in zone $\mathrm{C}(5.9 \%)$ (Tables 5, 6, 7).

The diameter of black alders in the study areas ranged from 1 to $39 \mathrm{~cm}$. The mean diameter of all black alders was $12.3 \mathrm{~cm}$. The mean diameter of trees was $11.4 \mathrm{~cm}$ in zone A, $14.5 \mathrm{~cm}$ in zone $\mathrm{B}$, and $19.0 \mathrm{~cm}$ in zone $\mathrm{C}$. The mean diameter of all cut black alders was $10.5 \mathrm{~cm}$.

Common aspen (Populus tremula) was represented by 257 trees, of which 117 (45.5\%) were cut by beavers. The species was most prevalent (119 trees) in study area No. 2, where it accounted for $46.3 \%$ of all aspens (Table 1). We observed the highest number of cut aspens (43) in research site No. 1 which occupied a woodland. In site No. 1 , cut aspens represented $36.75 \%$ of all aspens cut by beavers.

Common aspen was most prevalent in zone A ( 92 trees, 35.8\%), followed by zone B (91 trees, 35.4\%), and zone C (51 trees, 19.8\%). We found the highest number of cut aspens in zone A - 56 trees $(60.9 \%)$. Beavers cut 33 aspens in zone B (36.3\%) and 28 trees in zone $\mathrm{C}(37.8 \%)$ (Tables 5, 6, 7).

The diameter of aspens in the study areas ranged from 2 to $40 \mathrm{~cm}$. The mean diameter of all aspens was $17.3 \mathrm{~cm}$. The mean diameter of aspens was $16.7 \mathrm{~cm}$ in zone $\mathrm{A}, 18.6 \mathrm{~cm}$ in zone $\mathrm{B}$, and $16.4 \mathrm{~cm}$ in zone $\mathrm{C}$. The mean diameter of all cut aspens was $15.8 \mathrm{~cm}$.

Gray willow (Salix cinerea) was represented by 215 trees, of which 213 (98.6\%) were cut by beavers. The species was most prevalent (129 trees) in study area No. 8, where it accounted for $60 \%$ of all gray willows (Table 1). We observed the highest number of cut gray willows (128) in research site No. 8 which was occupied by nonforest tree and shrub communities. In site No. 8, cut willows represented $60.38 \%$ of all gray willows cut by beavers.

Gray willow was most prevalent in zone A (157 trees, $73 \%)$. Zone B was occupied by 18 gray willows $(8.4 \%)$, and zone $\mathrm{C}-$ by $40(18.6 \%)$. We found the highest number of cut gray willows in zone A (154 trees, $98.1 \%)$. Beavers cut 18 gray willows in zone $\mathrm{B}(100 \%)$ and 40 trees in zone C $(100 \%)$ (Tables 5, 6, 7).

The diameter of gray willows in the study areas ranged from 1 to $11 \mathrm{~cm}$. The mean diameter of all gray willows was $2.9 \mathrm{~cm}$. The mean diameter of gray willows was 3.1 $\mathrm{cm}$ in zone A, $2.4 \mathrm{~cm}$ in zone $\mathrm{B}$, and $2.6 \mathrm{~cm}$ in zone $\mathrm{C}$. The mean diameter of all cut gray willows was $2.9 \mathrm{~cm}$.

White willow (Salix alba) was represented by 142 trees, of which 105 (73.9\%) were cut by beavers. The species was most prevalent (107 trees) in study area No. 4, where it accounted for $75.35 \%$ of all white willows (Table 1). We observed the highest number of cut white willows (89) in research site No. 4 which occupied a woodland. In site No. 4 , cut willows represented $84.76 \%$ of all white willows cut by beavers.

White willow was most prevalent in zone A (107 trees, 75.4\%). Zone B was occupied by 25 white willows (17.6\%), and zone $\mathrm{C}-$ by $10(7 \%)$. We found the highest number of cut white willows in zone A (74 trees, $69.2 \%)$. Beavers cut 25 white willows in zone B (100\%) and 6 trees in zone C (60\%) (Tables 5, 6, 7). 
Table 5. Percentage (\%) of trees representing I class in A riparian zone

\begin{tabular}{|c|c|c|c|c|c|c|c|c|c|c|c|c|}
\hline \multirow{2}{*}{ Lp. } & \multirow{2}{*}{ Species } & \multirow{2}{*}{$\begin{array}{c}(\%) \\
\text { class I }\end{array}$} & \multirow{2}{*}{$\begin{array}{c}\text { (No.) } \\
\text { total in zone A }\end{array}$} & \multicolumn{9}{|c|}{ p value } \\
\hline & & & & 1 & 2 & 3 & 4 & 5 & 6 & 7 & 8 & 9 \\
\hline 1 & Betula pubescens & 45,90 & 329 & - & & & & & & & & \\
\hline 2 & Alnus glutinosa & 8,86 & 587 & $<0,001$ & - & & & & & & & \\
\hline 3 & Populus tremula & 60,87 & 92 & 0,162 & $<0,001$ & - & & & & & & \\
\hline 4 & Salix cinerea & 98,09 & 157 & $<0,001$ & $<0,001$ & $\mathbf{0 , 0 2 1}$ & - & & & & & \\
\hline 5 & Salix alba & 69,16 & 107 & $\mathbf{0 , 0 2 7}$ & $<0,001$ & 0,650 & 0,075 & - & & & & \\
\hline 6 & Tilia cordata & 75,93 & 54 & $\mathbf{0 , 0 3 2}$ & $<0,001$ & 0,423 & 0,293 & 0,797 & - & & & \\
\hline 7 & Quercus robur & 10,34 & 29 & 0,008 & 0,740 & 0,002 & $<0,001$ & $<0,001$ & $<0,001$ & - & & \\
\hline 8 & Frangula alnus & 14,58 & 48 & $\mathbf{0 , 0 0 3}$ & 0,308 & $<0,001$ & $<0,001$ & $<0,001$ & $<0,001$ & 0,739 & - & \\
\hline 9 & Pinus sylvestris & 0,00 & 5 & 0,331 & 1,000 & 0,159 & 0,061 & 0,159 & 0,076 & 1,000 & 1,000 & - \\
\hline 10 & Fraxinus excelsior & 63,16 & 19 & 0,429 & $<0,001$ & 1,000 & 0,265 & 0,846 & 0,682 & $\mathbf{0 , 0 0 8}$ & $\mathbf{0 , 0 0 7}$ & 0,146 \\
\hline
\end{tabular}

$\mathrm{p} \leq 0,01$ - Difference is statistically highly significant 
Table 6. Percentage (\%) of trees representing I class in B riparian zone

\begin{tabular}{|c|c|c|c|c|c|c|c|c|c|c|c|c|c|}
\hline \multirow[t]{2}{*}{ Lp. } & \multirow[t]{2}{*}{ Species } & \multirow{2}{*}{$\begin{array}{c}(\%) \\
\text { class I }\end{array}$} & \multirow{2}{*}{$\begin{array}{l}\text { (No.) } \\
\text { total in zone } B\end{array}$} & \multicolumn{10}{|c|}{ p value } \\
\hline & & & & 1 & 2 & 3 & 4 & 5 & 6 & 7 & 8 & 9 & 10 \\
\hline 1 & Betula pubescens & 20,54 & 185 & - & & & & & & & & & \\
\hline 2 & Alnus glutinosa & 9,88 & 81 & 0,078 & - & & & & & & & & \\
\hline 3 & Populus tremula & 36,26 & 91 & $\mathbf{0 , 0 3 8}$ & 0,001 & - & & & & & & & \\
\hline 4 & Salix cinerea & 100,00 & 18 & $<0,001$ & $<0,001$ & 0,014 & - & & & & & & \\
\hline 5 & Salix alba & 100,00 & 25 & $<0,001$ & $<0,001$ & 0,004 & 1,000 & - & & & & & \\
\hline 6 & Tilia cordata & 51,35 & 37 & 0,009 & $<0,001$ & 0,375 & 0,135 & 0,116 & - & & & & \\
\hline 7 & Quercus robur & 25,00 & 16 & 0,758 & 0,227 & 0,783 & 0,045 & $\mathbf{0 , 0 3 1}$ & 0,395 & - & & & \\
\hline 8 & Pinus sylvestris & 0,00 & 9 & 0,362 & 1,000 & 0,111 & $\mathbf{0 , 0 0 7}$ & 0,007 & 0,049 & 0,280 & - & & \\
\hline 9 & Picea abies & 0,00 & 21 & 0,052 & 0,349 & 0,004 & $<0,001$ & $<0,001$ & $<0,001$ & 0,048 & 1,000 & - & \\
\hline 10 & Crataegus mon. & 62,5 & 8 & 0,065 & 0,011 & 0,349 & 0,532 & 0,542 & 0,756 & 0,425 & 0,054 & 0,005 & - \\
\hline 11 & Pyrus communis & 0,00 & 6 & 0,593 & 1,000 & 0,337 & $\mathbf{0 , 0 2 9}$ & 0,028 & 0,165 & 0,542 & 1,000 & 1,000 & 0,128 \\
\hline
\end{tabular}

$\mathrm{p} \leq 0,01-$ Difference is statistically highly significant 
Table 7. Percentage (\%) of trees representing I class in C riparian zone

\begin{tabular}{|c|c|c|c|c|c|c|c|c|c|c|c|c|}
\hline \multirow[t]{2}{*}{ Lp. } & \multirow[t]{2}{*}{ Species } & \multirow{2}{*}{$\begin{array}{c}(\%) \\
\text { class I }\end{array}$} & \multirow{2}{*}{$\begin{array}{c}\text { (No.) } \\
\text { total in zone } C\end{array}$} & \multicolumn{9}{|c|}{ p value } \\
\hline & & & & 1 & 2 & 3 & 4 & 5 & 6 & 7 & 8 & 9 \\
\hline 1 & Betula pubescens & 13,33 & 210 & - & & & & & & & & \\
\hline 2 & Alnus glutinosa & 5,88 & 51 & 0,227 & - & & & & & & & \\
\hline 3 & Populus tremula & 37,84 & 74 & $<0,001$ & $<0,001$ & - & & & & & & \\
\hline 4 & Salix cinerea & 100,00 & 40 & $<0,001$ & $<0,001$ & 0,002 & - & & & & & \\
\hline 5 & Salix alba & 60,00 & 10 & 0,011 & $\mathbf{0 , 0 0 3}$ & 0,392 & 0,420 & - & & & & \\
\hline 6 & Tilia cordata & 19,23 & 26 & 0,558 & 0,134 & 0,242 & 0,001 & 0,148 & - & & & \\
\hline 7 & Quercus robur & 21,28 & 47 & 0,271 & 0,075 & 0,179 & $<0,001$ & 0,101 & 1,000 & - & & \\
\hline 8 & Frangula alnus & 55,56 & 18 & 0,002 & $<0,001$ & 0,482 & 0,271 & 1,000 & 0,134 & 0,101 & - & \\
\hline 9 & Pinus sylvestris & 0,00 & 38 & 0,019 & 0,265 & $<0,001$ & $<0,001$ & $<0,001$ & $\mathbf{0 , 0 1 5}$ & $\mathbf{0 , 0 0 5}$ & $<0,001$ & - \\
\hline 10 & Acer platanoides & 2,94 & 34 & 0,145 & 1,000 & 0,001 & $<0,001$ & 0,003 & 0,091 & $\mathbf{0 , 0 4 7}$ & 0,001 & 0,479 \\
\hline
\end{tabular}

$\mathrm{p} \leq 0,01$ - Difference is statistically highly significant 
The diameter of white willows in the study areas ranged from 2 to $50 \mathrm{~cm}$. The mean diameter of all white willows was $9.7 \mathrm{~cm}$. The mean diameter of white willows was 8.6 $\mathrm{cm}$ in zone A, $8.0 \mathrm{~cm}$ in zone $\mathrm{B}$, and $26.5 \mathrm{~cm}$ in zone C. The mean diameter of all cut white willows was $9.0 \mathrm{~cm}$.

Small-leaved lime (Tilia cordata) was represented by 117 trees, of which 65 (55.6\%) were cut by beavers. The species was most prevalent (60 trees) in study area No. 7, where it accounted for $51.28 \%$ of all limes (Table 1). We also observed the highest number of cut limes (33) in research site No. 7 which was occupied by non-forest tree and shrub communities. In site No. 7, cut limes represented $50.77 \%$ of all limes cut by beavers.

Small-leaved lime was most prevalent in zone A (54 trees, 46.2\%). Zone B was occupied by 37 limes (31.6\%), and zone C - by $26(22.2 \%)$. We found the highest number of cut limes in zone A (41 trees, $75.9 \%)$. Beavers cut 19 limes in zone B $(51.4 \%)$ and 5 limes in zone C (19.2\%) (Tables 5, 6, 7).

The diameter of limes in the study areas ranged from 2 to $27 \mathrm{~cm}$. The mean diameter of all limes was $5.0 \mathrm{~cm}$. The mean diameter of limes was $5.1 \mathrm{~cm}$ in zone A, $4.4 \mathrm{~cm}$ in zone $\mathrm{B}$, and $5.8 \mathrm{~cm}$ in zone $\mathrm{C}$. The mean diameter of all cut limes was $4.4 \mathrm{~cm}$.

Pedunculate oak (Quercus robur) was represented by 92 trees, of which 16 (17.4\%) were cut by beavers. The species was most prevalent (40 trees) in study area No. 2, where it accounted for $43.48 \%$ of all oaks (Table 1). We observed the highest number of cut oaks in research sites No. 3 (5) and 4 (5) which occupied woodlands. In those study areas, cut oaks represented $29.41 \%$ of all pedunculate oaks cut by beavers.

Pedunculate oak was most prevalent in zone C (47 trees, 51.1\%). Zone A was occupied by 29 oaks $(31.5 \%)$, and zone B - by $16(17.4 \%)$. We found the highest number of cut oaks in zone $\mathrm{C}(10$ trees, $21.3 \%)$. Beavers cut 4 oaks in zone B $(25.0 \%)$ and only 3 trees in zone $\mathrm{C}(10.3 \%)$ (Tables $5,6,7)$.

The diameter of oaks in the study areas ranged from 2 to $36 \mathrm{~cm}$. The mean diameter of all oaks was $13.0 \mathrm{~cm}$. The mean diameter of oaks was $7.9 \mathrm{~cm}$ in zone A, $7.4 \mathrm{~cm}$ in zone $\mathrm{B}$, and $16.9 \mathrm{~cm}$ in zone $\mathrm{C}$. The mean diameter of all cut oaks was $12.1 \mathrm{~cm}$.

Alder buckthorn (Frangula alnus) was represented by 68 trees, of which 17 (26.0\%) were cut by beavers. The species was most prevalent (28 trees) in study area No. 3, where it accounted for $41.18 \%$ of all alder buckthorns (Table 1). We observed the highest number of cut alder buckthorns (8) in research site No. 7 which was occupied by non-forest tree and shrub communities. In study area No. 7, cut trees of the discussed species represented $47.06 \%$ of all alder buckthorns cut by beavers.

Alder buckthorn was most prevalent in zone A (48 trees, 70.6\%); only 2 alder buckthorns $(2.9 \%)$ were found in zone B, and $18(26.5 \%)$ in zone C. We found the highest number of cut alder buckthorns in zone $\mathrm{C}$ (10 trees, 55.6\%) and zone A ( 7 trees, 14.6\%) (Tables 5, 6, 7).

The diameter of alder buckthorns in the study areas ranged from 1 to $12 \mathrm{~cm}$. The mean diameter of all alder buckthorns was $4.8 \mathrm{~cm}$. The mean diameter of alder buckthorns was $4.8 \mathrm{~cm}$ in zone A, $5 \mathrm{~cm}$ in zone $\mathrm{B}$, and $4.9 \mathrm{~cm}$ in zone $\mathrm{C}$. The mean diameter of all cut alder buckthorns was $4.2 \mathrm{~cm}$.

Scots pine (Pinus sylvestris) was represented by 52 trees, of which only 2 (4\%) were partially cut by beavers, and no trees were felled. The species was most prevalent (24 trees) in study area No. 2, where it accounted for $46.15 \%$ of all pines. 
Scots pine was most prevalent in zone C (38 trees, $73.1 \%$ ). Zone B was occupied by 9 pines $(17.3 \%)$, and zone A - by $5(9.6 \%)$. The mean diameter of all pines was $22.4 \mathrm{~cm}$. The mean diameter of pines was $16 \mathrm{~cm}$ in zone A, $19 \mathrm{~cm}$ in zone B, and $24 \mathrm{~cm}$ in zone C.

Norway maple (Acer platanoides) was represented by 34 trees, of which only $1(3.0 \%)$ was cut by beavers. The species was most prevalent (30 trees) in study area No. 4, where it accounted for $88.24 \%$ of all maples (Table 1). Beavers cut only 1 maple in research site No. 4 comprised of wooded areas. Norway maple occupied only riparian zone C.

Common spruce (Picea abies) was represented by 25 trees, and it accounted for only $1 \%$ of all analyzed tree species. Common spruces were not cut down by beavers.

The remaining tree species (common ash, common hawthorn, European pear, field elm, common hornbeam and rowan) accounted for less than $1 \%$ of all identified taxa.

Riparian zone A was occupied by a total of 1431 trees, of which 551 (38.5\%) were cut and $98(6.85 \%)$ were partly cut by beavers. Riparian zone B was occupied by 503 trees, of which $152(30.22 \%)$ were cut and $17(3.38 \%)$ were partly cut by beavers. Riparian zone $\mathrm{C}$ was occupied by 566 trees, of which 133 (23.5\%) were cut and 15 (2.65\%) were partly cut by beavers (Tables 5, 6, 7).

In all study areas, 1427 trees $(57.08 \%)$ were less than $10 \mathrm{~cm}$ in diameter. We determined the number of trees with a diameter smaller than $10 \mathrm{~cm}$ at $844(61.77 \%)$ in zone A, at $224(44.53 \%)$ in zone B, and at $319(56.36 \%)$ in zone C. In the total number of trees cut in all study areas, $101(12.08 \%)$ were larger than $15 \mathrm{~cm}$ in diameter. We determined the number of cut trees with a diameter larger than $15 \mathrm{~cm}$ at $50(9.1 \%)$ in zone $\mathrm{A}$, at $32(21 \%)$ in zone $\mathrm{B}$, and at $19(14.28 \%)$ in zone $\mathrm{C}$ (Table 4$)$.

\section{Discussion}

The results of this study and the findings of other authors clearly indicate that willows, aspens and alders are most commonly cut by beavers in the fall and winter (Ficek, 2003; Vorel et al., 2015; O'Connell et al., 2008; Goryainova et al., 2014). In some studies, beavers chose other species of trees and shrubs, such as Corylus avellana (Margaletic et al., 2006). Interestingly, beavers relatively often opted for alder buckthorn ( $26 \%$ trees cut) and pedunculate oak (more than $17 \%$ trees cut) in the current study. Gorshkov and Gorshkov (2011) investigated the foraging behavior of the European beaver in the Republic of Tatarstan (European Russia). The authors analyzed 14000 cut trees and concluded that the foraging preferences of beavers are largely determined by the availability of different tree species in the riparian zone. In the cited study, beavers cut mostly willows (Salix triandria and Salix dasyclados), which accounted for $92 \%$ of all cut trees; whereas willows that were less than $10 \mathrm{~cm}$ in diameter accounted for $81 \%$ of cut trees. Alder was the second most frequently felled tree, and it accounted for $3 \%$ of all cut trees. The cited authors did not report correlations between beaver foraging preferences and the diameter of most tree species, excluding willows and aspens. To cut thicker trees, beavers have to spend more time on land, which increases the risk of a predatory attack. For this reason, beavers select trees not only based on the species, but also based on the diameter of the trunk. In the present study, differences were noted in beavers' preferences for trees that were up to $15 \mathrm{~cm}$ in diameter and trees that were larger than 15 in diameter, across the analyzed riparian zones (Table 4). On average, nearly $88 \%$ (79.0\% to $90.9 \%)$ of the trees cut by beavers had diameters of up to $15 \mathrm{~cm}$. 
Information about the foraging behavior and preferences of beavers not only expands our knowledge about the species, but also has practical implications. Based on the choices made by beavers, researchers are able to identify the optimal habitats for beavers and estimate the rate at which these animals utilize riparian vegetation. Selective foraging on tree species by beavers in different biotopes is another important consideration. In our study, we observed the highest number of trees damaged by beavers in woodlands and in non-forest tree and shrub communities. Czyżowski et al. (2009) also reported valuable data in a study comparing the foraging preferences of beavers in an urban area (city of Lublin, Poland) and a nature reserve. Their research was conducted near the study areas analyzed in our experiment. In the cited study, white willow and black alder were also most frequently selected by beavers, which can be attributed to the prevalence of these species in the investigated area. In the nature reserve, beavers opted mostly for trees with thinner trunks. The number of damaged trees decreased with an increase in their breast height diameter. The cited authors did not report such a correlation in the analyzed urban area. Beavers also showed a preference for trees representing the most common diameter ranges. The above results suggest that beavers actively select their food sources in natural habitats that are not exposed to external pressures.

In addition to tree species and diameter, beaver foraging preferences are also affected by the distance from the shoreline of a river, watercourse or a water body. Czyżowski et al. (2009) analyzed the depth of incisions made by beavers in trees, subject to the distance from the shoreline. Their findings revealed that beavers most readily foraged for trees and shrubs situated within a distance of $50 \mathrm{~m}$ from a watercourse. Trees were most frequently cut in the immediate vicinity of water bodies, but damage to shrubs was noted even within a distance of $80 \mathrm{~m}$ from the shore. Shrubs are easy to cut and transport, which prompts beavers to travel greater distances in search of this source of food and building material. The majority of trees cut by beavers were situated within a distance of $10 \mathrm{~m}$ from the shoreline (Czyżowski et al., 2009). In the Jamy Forest Division in central Poland, beavers showed a preference for trees with a diameter of up to $15 \mathrm{~cm}$, growing within a distance of $15 \mathrm{~m}$ from the shore (Janiszewski et al., 2012). The results of our study and the findings of other authors suggest that beavers concentrate their feeding activity in riparian zones that are $15 \mathrm{~m}$ in width. According to Goryainova et al. (2014), beavers generally do not forage further than $50 \mathrm{~m}$ away from the shore in early stages of habitat colonization. When local food resources are depleted, the foraging zone can be expanded to $165 \mathrm{~m}$ from the shoreline in the absence of pressure from predators. Gorshkov and Gorshkov (2011) demonstrated that the foraging preferences of beavers were more strongly manifested at greater distances from a water body. Aspens were cut at a distance of up to $60 \mathrm{~m}$ from the shore, whereas other tree species were damaged mostly within a 10-meter-wide riparian zone.

Nolet et al. (1994) suggested that beaver preferences for tree species could be influenced by the demand for specific nutrients. Beavers could choose hazels and ashes due to their high sodium content, and plum trees and poplars on account of their high phosphorus levels. Therefore, the collection and selection of varied food resources could be a strategy that minimizes the risk of nutrient deficiencies in the European beaver.

Douced and Fryxell (1993) analyzed the relationships between the nutritional value of plant material and the foraging preferences of the Canadian beaver Castor canadensis. They found that feeding preferences were not significantly correlated with the energy value or the content of dry matter, energy, total protein or fiber in the analyzed food resources. The cited 
authors suggested that beavers and many other herbivorous vertebrates choose foods that are ample sources of energy. Similar results were reported by Jenkins (1981) who observed that beavers require diverse diets containing various species of plants. When captive beavers were fed monotonous diets composed of aspens only, their body weights decreased. The animals lost more nitrogen than they took in, and their calcium and phosphorus levels were unbalanced. For this reason, free living beavers supplement their diets with aquatic vegetation in the fall and winter when the availability of herbage is limited (Dezhkin et al., 1986). This is particularly important during breeding and nursing when the nitrogen and phosphorus requirements of animals increase six-fold relative to other seasons of the year. Beavers compensate for these demands by foraging on aquatic and herbaceous vegetation (Nolet et al., 1995). In the fall and winter, the animals cut down Corylus, Fraxinus (Na), Prunus and Populus (P) to avoid the above macronutrient deficiencies (Nolet et al., 1994).

The biomass of cut trees and shrubs is not fully utilized as food or building material by beavers. On average, beavers eat only round $30 \%$ of the collected woody plants, and the remaining resources are left to decompose naturally in the ecosystem. The animals have strong preferences for willows and aspens, which can slow down the succession of these species in floodplains. This process contributes to the growth of other plant species and creates a supportive habitat for aquatic fauna (Janiszewski et al., 2014). Beavers also use shoots and branches from cut trees to build dams. The selection of building materials is determined by the availability of trees in riparian zones, and beavers do not discriminate tree and shrub species based on their suitability for dam construction (Janiszewski et al., 2006).

\section{REFERENCES}

[1] Czyżowski, P., Karpiński, M., Drozd L. (2009): Forage preferences of the European Beaver (Castor fiber L.) on urban and protected areas. - Sylwan 153 (6): 425-432. [In Polish with English summary].

[2] Danilov, P.I., Fyodorov, F.V. (2015): Comparative Characterization of the Building Activity of Canadian and European Beavers in Northern European Russia. - Russian Journal of Ecology 46 (3): 272-278.

[3] Dezhkin, V.V., Djakov, I.V., Safonov V.G. (1986): Bobr. - Agropromizdat, Moskva. [In Russian].

[4] Doucet, M.C., Fryxell, J.M. (1993): The effect of nutritional quality of forage preferences by beavers. - OIKOS 67: 201-208.

[5] Ficek, A. (2003): Zivotni prostredi, potravni a stavebni cinnost bobra evropskeho (Castor fiber L. 1758) na uzemi Ceske Republiky. - Folia Venatoria 33: 97-96. [In Slovak with English summary].

[6] Gorshkov, D., Gorskhov, Y. (2011): Feeding strategy of beavers in Tatarstan Republic. In: Sjöberg, G., Ball, J.P. (eds.) Restoring the European Beaver: 50 Years of Experience. - Pensoft, Sofia-Moscow.

[7] Goryainova, Z.I., Katsman, E.A., Zavyalov, N.A., Khlyap, L.A. Petrosyan, V.G. (2014): Evaluation of Tree and Shrubs Resources of the Eurasian Beaver (Castor fiber L.) and Changes in Beaver Foraging Strategy after Resources Depletion. -Russian Journal of Biological Invasions 5(4): 242-254.

[8] Janiszewski, P., Gugołek, A., Łobanowska, A. (2006): Use of shoreline vegetation by the European beaver (Castor fiber L.). - Acta Scientiarum Polonorum Silvarum Colendarum Ratio et Industria Lignaria 5(2): 63-70.

[9] Janiszewski, P., Misiukiewicz, W. (2012): Bóbr europejski Castor fiber. - BTLWorks, Warszawa. 
[10] Janiszewski, P., Hanzal, V., Misiukiewicz, W. (2014): The European Beaver (Castor fiber) as a Keystone Species - a Literature Review. - Baltic forestry 20 (2): 277-286.

[11] Janiszewski, P., Hanzal, V., Weber, B., Gugolek, A. (2012): Characteristic of riparian trees and shrubs utilized by the European beaver (Castor fiber) in the Jamy Forest District. - Annales UMCS. Sectio EE 4: 26-33.

[12] Jenkins, S.H. (1981): Problems, progress, and prospects in studies of food selection by beavers. In: Chapman, J.A., Pursley, D. (eds.) Worldwide Furbearer Conferences Procedings I: 559-579.

[13] Logofet, D.O., Evstigeev, O.I., Aleinikov, A.A., Morozova, A.O. (2016): Succession Caused by Beaver (Castor fiber L.) Life Activity: II. A Refined Markov Model. - Biology Bulletin Reviews 6(1): 39-56.

[14] Margaletic, J., Grubesic, M., Dusak, V., Konjevic, D. (2006): Activity of European beavers (Castor fiber L.) in young pedunculate oak (Quercus robur L.) forests. Veterinaski Arhiv 76 (Suppl.): 167-175.

[15] Nolet, B.A., Hoekstra, A., Ottenheim, M.M. (1994): Selective foraging on woody species by the Beaver Castor fiber, and its impact on a riparian willow forest. - Biological Conservation 70: 117-128.

[16] Nolet, B.A., van Der Veer, P.J., Evers, E.G.J., Ottenheim, M.M. (1995): A linear programming model of diet choice of free-living beaver. - Netherlands Journal of Zoology 45 (3-4): 315-337.

[17] Nummi, P. (1989): Simulated effect of the beaver on vegetation, invertebrates and ducks. - Annales Zoologici Fennici 26: 43-52.

[18] O'Connell, M.J., Atkinson, S.R., Gamez, K., Pickering, S.P., Dutton, J.S. (2008): Forage Preferences of the European Beaver Castor fiber: Implication for Re-introduction. Conservation \& Society 6: 190-194.

[19] Radwan, S (ed.) (2002): Poleski Park Narodowy. - Wydawnictwo Morpol, Lublin. [in Polish]

[20] Rosell, F., Bozser, O., Collen, P., Parker H. (2005): Ecological impact of beaver Castor fiber and Castor canadensis and their ability to modify ecosystes. - Mammal Review 35(3-4): 248-276.

[21] Vecherskii, M.V., Naumova, E.I., Kostina, N.V., Umarov M.M. (2006): Some Specific Features of Nitrogen Fixation in the Digestive Tract of the European Beaver (Castor fiber). - Doklady Biological Science 411: 452-454.

[22] Vorel, A., Valkova, L., Hamsikova, L., Malon, J., Korbelova, J. (2015): Beaver foraging behaviour: Seasonal foraging specialization by a choosy generalist herbivore. Behavioral Ecology and Sociobiology 69: 1221-1235. 